\title{
Implementation of Six Sigma Method in Small and Medium Enterprises (SMEs) (Case Study on CV. Berkah Abadi)
}

\author{
M. ABDILLAH RORKE ILYASA ${ }^{1}$, MERITA BERNIK ${ }^{2}$, BUDI HARSANTO ${ }^{2}$ \\ 1 Student Of Universitas Padjadjaran, Bandung 40123, Indonesia \\ ${ }^{2}$ Lecturer at Universitas Padjadjaran, Bandung 40132, Indonesia \\ Email correspondence: abdillah.rorke@gmail.com,meritabernik26@gmail.com, budi.harsanto@gmail.com
}

\begin{abstract}
The increasing economic growth in Indonesia encourages the growth of SMEs (Small and Medium Enterprises). This condition results in the intense competition among similar SMEs. This encourages companies to always produce quality products in order to meet customers' satisfaction. One of the methods to control the quality is by using Six Sigma. Six sigma is a method of improving the quality towards the target of 3.4 failures per million opportunities for each production of goods and services. Six sigma is divided into two methods, namely DMAIC (Define, Measure, Analyze, Improve, Control) and DMADV (Define, Measure, Analyze, Design, Verify). Six Sigma can be implemented not only for big companies but also for SMEs. This study was conducted to determine the application of quality control aspect of Six Sigma in CV. Berkah Abadi as an SME in producing shoes under the name BNA. This study utilized DMAIC metghod. By using Six Sigma, it can be seen that the sigma value in the production process of CV Berkah Abadi is 3,274 with the possibility of error products contained is 38758.87 in a million occasions. In the application of Six Sigma in this study, there are six causes of defective products, namely untidy glue application (41.7\%), stains (23.8\%), squiggled pattern $(11.9 \%)$, untidy stitches neat (10.4\%), wrinkles (8.9\%) and torn materials $(2.9 \%)$.
\end{abstract}

Key words: Quality Control, Six Sigma, SMEs, Shoe Industry, Bandung-Indonesia.

\section{Implementasi Metode Six Sigma di Usaha Kecil dan Menengah (UKM) (Studi Kasus pada CV. Berkah Abadi)}

\begin{abstract}
Abstrak
Meningkatnya pertumbuhan ekonomi di Indonesia mendorong pertumbuhan UKM (Usaha Kecil dan Menengah). Kondisi ini menyebabkan persaingan yang ketat di antara UKM yang sama. Hal ini mendorong perusahaan untuk selalu menghasilkan produk berkualitas dalam rangka memenuhi kepuasan pelanggan. Salah satu metode untuk mengontrol kualitas adalah dengan menggunakan Six Sigma. Six sigma adalah metode meningkatkan kualitas menuju target 3,4 kegagalan per sejuta kesempatan untuk setiap produksi barang dan jasa. Six sigma dibagi menjadi dua metode, yaitu DMAIC (Define, Measure, Analyze, Improve, Control) dan DMADV (Define, Measure, Analyze, Desain, Verifikasi). Six Sigma dapat diimplementasikan tidak hanya untuk perusahaan besar, tetapi juga untuk UKM. Penelitian ini dilakukan untuk mengetahui penerapan aspek pengendalian kualitas Six Sigma di CV. Berkah Abadi sebagai UKM dalam memproduksi sepatu dengan nama BNA. Penelitian ini dimanfaatkan metode DMAIC. Dengan menggunakan Six Sigma, dapat dilihat bahwa nilai sigma dalam proses produksi CV Berkah Abadi adalah 3274 dengan kemungkinan produk kesalahan yang terkandung adalah 38.758,87 dalam satu juta kesempatan. Dalam penerapan Six Sigma dalam penelitian ini, ada enam penyebab produk cacat, yaitu aplikasi lem sol tidak rapi $(41,7 \%)$, kotor $(23,8 \%)$, coretan pola $(11,9 \%)$, jahitan tidak rapi (10,4\%), kerut ( $8,9 \%)$ dan bahan sobek (2,9\%).
\end{abstract}

Kata kunci: Kontrol Kualitas, Six Sigma, UKM, Industri Sepatu, Bandung-Indonesia. 


\section{INTRODUCTION}

SME sector has been promoted and used as the main agenda of economic development of Indonesia. SME sector has proven resilient when the economy crises striking in 1998, SME sector and also many established companies that survived the crises, while the larger sectors were actually uprooted by the crisis. In an article published in Bisnis Indonesia on October 21, 2008, Mudradjad Kuncoro suggested that SMEs were proved to be resistant to the crisis and were able to survive because they have debt from foreign banks debt. Secondly, not a lot of debts to banks because owner's equity. Third, the use of local inputs. Fourth, export-oriented.

One of the opportunities and challenges of SMEs is the program AEC (ASEAN Economic Community) held the end of 2015. AEC allow products from other ASEAN countries to enter into the country with a low price, which could threaten the existence of SMEs business. But on the other hand this could be an opportunity for SMEs whose products are qualified to be able to expand the ASEAN market.

Being aware of the challenges and opportunities of SMEs in the global competitive businesses, the Indonesian government is actively launching programs that urge people to entrepreneurship and programs pro SMEs, ranging from training, the establishment of the business community, the exhibition of products, technology transfer and others. These programs have proven successful in increasing the growth of SMEs that produce a quality product with high competitiveness. Region with the largest growth rate of SMEs is in West Java. According to data from the Ministry of Cooperatives in West Java, in 2011, the growth of micro enterprises amounted to 6.35\%, $8.97 \%$ small businesses and medium-sized enterprises reached $11.62 \%$, while in 2012 recorded growth of micro enterprises amounted to $7.08 \%, 7.78 \%$ of small businesses and medium-sized enterprises reached $5.78 \%$.

One way to win a tight competition is to improve product quality. SMEs that can survive and thrive in the national and global competition must be able to deliver products in the form of goods or services of better quality, more competitive price, faster delivery and better service than competitors. To meet the customer satisfaction, product quality is a very important thing to manage. Excellent quality can avoid repair costs, which ultimately will make the company's operations to be more efficient and effective, and therefore the company should continue to perform quality control (Department of Cooperatives and Micro, Small and Medium Enterprises of West Java province in 2013).

One method utilized to improve the quality of products/services is Six Sigma (Heizer and Render, 2011: 227). Six Sigma is a management tool that focuses on quality control by studying the company's overall production system. Six Sigma aims to eliminate defects, cut the time of making the product, and reduce costs. Six sigma is a comprehensive system namely the strategy, discipline, and tool to achieve and support business success. Six Sigma focuses on improving customer satisfaction because it includes a method named DMAIC (Define, Measure, Analyze, Improve, Control (Gijo and Jiju, 2011).

As mentioned above, the rate of growth of SMEs can be quite rapidly, creating intense competition as well as competition SMEs shoes. In Cibaduyut, a shoe industry center in Bandung City, West Java, Indonesia, There are 577 shoe companies with a total workforce of 3008 employees (sentraindustribandung.com). The data does not include the number of companies outside the area of Cibaduyut. One of the companies is CV. Berkah Abadi which is established in 2011. Currently, CV Berkah Abadi has its own shoe brands, including BNA, Devinata and JNB, and the company focuses on producing Docmart-like shoes. CV Berkah Abadi also accepts shoe orders in large numbers.

In the production process, CV Berkah Abadi often produces defective products. Employees who are less focus in production process generate less optimal products, for example ink scratch on the shoes, insoles which are not glued well to the shoes, as well as the occurrence of wrinkles on the shoes. By using Six Sigma, the company is expected to reduce the number of defective products significantly.

Below is data on the number of Docmart-like shoes produced by CV Berkah Abadi from May to September 2014: 
JURNAL BISNIS \& MANAJEMEN

ISSN 1412 - 3681

Table 1 Total Production of Docmart-like shoes of CV. Berkah Abadi from May-September 2014

\begin{tabular}{ccccccc}
\hline Month & MEI & JUNE & JULY & AGS & SEP & TOTAL \\
\hline $\begin{array}{c}\text { Total } \\
\text { Production }\end{array}$ & 570 & 750 & 630 & 650 & 660 & 3260 \\
\hline SOurce: & & & & & \\
\hline
\end{tabular}

Source: Internal data of CV. Berkah Abadi

Based on information from the CEO of CV. Berkah Abadi, the average defective production experienced by each period is by $10 \%$, meaning that the total defective products from May to September 2014 were 3260 pairs of shoes. It is beyond the defective products that occur in every process. Problems encountered by CV Berkah Abadi was a lack of control in shoe production processes which resulted in defective products, production quality standard.

This study focused on the quality control process of Docmart-like shoes. Based on the problem background, this study aimed to find out the factors that cause defects and the implementation of Six Sigma in the production process of Docmart-like shoes in CV. Berkah Abadi.

\section{LITERATURE REVIEW}

Basically, customers will be satisfied when they receive value as they expect. If the products (goods and/services) are processed at the rate of Six Sigma quality, the company can expect 3.4 failures per million opportunities (DPMO) or 99.99966 percent of what is expected by the customer. Six Sigma can be regarded as a breakthrough strategy that allows the company to increase its outstanding (dramatic). Six sigma can be viewed as the control process of industry to focus on the customer, by emphasizing the ability of the process (process capability).

There are many experts who reveal the description of Six Sigma. The followings are several definitions of Six Sigma by some experts. According to Pande and Holpp (2005: 4), Six Sigma is " the total commitment of the management and also the philosophy to excellence, customer focus, repair/improvement of processes, and the rules of measurement (not just a feeling)." Next, Gaspersz (2002: 9) stated that Six Sigma is " a quality improvement vision towards the target of 3.4 failures per million opportunities for each transaction of goods and services. Six sigma is a vigorous effort towards perfection (zero defect - zero failure)." Then, Heizer and Render (2011: 227) prosposed that Six Sigma is "a program designed to reduce defects to help lower costs, save time, and improve customer satisfaction". Six sigma is a program designed to eliminate disability to help with low cost, save time, and improve customer satisfaction.

According to Gaspersz (2002: 9), there are six key aspects that need to be considered in the application of Six Sigma concepts, namely; (1) Identifying customers, (2) Identifying product, (3) Identifying the customer needs for product, (4) Identifying the process, (5) Avoiding errors in the process and eliminating all of the existing waste, (6) Improving the process continuously towards the target of Six Sigma.

On the other hand, according to Pete and Hollp (2005: $20)$, there are six major themes in six sigma, namely:

\section{Focusing earnest on customers}

Customers are the top priority for the implementation of Six Sigma project. Six sigma explains how the company determines customer requirements, so as to meet the wishes and needs of customers.

\section{Management is driven by data and facts}

Six sigma takes the attitude of "management that is driven by data and facts." Six Sigma begins by determining the key measures of business performance. Then, apply the data and analysis to build an understanding of the key variables and optimal results.

\section{Focus on process}

In Six Sigma, process is the phase to start the action. Six sigma convinces leaders and managers that process is a way to build competitive advantage and deliver value to the customer.

\section{Proactive Management}

Proactive is opposed to reactive, which means acting before the occurrence of an event. But in the real world, proactive measures are often ignored, for example setting clear priorities and focusing on prevention against troubleshoot problems. Six sigma includes a number of tools and practices that replace reactive habits with proactive, dynamic and responsive management styles. 


\section{Collaboration without borders}

Six sigma expands opportunities for collaboration if people in the company can carry out their rights and obligations in a balanced manner. Thus, there is no great interdependence in a process in all parts.

\section{The drive to perfect, tolerance to failure}

Six sigma encourages companies to continually move towards perfection and be willing to accept and manage setbacks occurrence.

Based on the description above, it can be concluded that Six Sigma is a method of quality control to minimize defects in the products produced by the company with the scale of 3.4 out of a million chances. Six sigma is a discipline that is based on data and facts and refers to customer.

According to Gaspersz (2002: 8), Define, Measure, Analyze, Improve and Control (DMAIC) is a process for continuous improvement towards the target of Six Sigma. The elements of DMAIC are futher described as follows:

\section{Define}

Define is the targeting measure of Six Sigma quality improvement activities. This step is to define plans of action that should be taken to implement the improvement of every stage of key business processes. According to Pande and Cavanagh (2003: 166), the three main activities related to the core process and customers are; (1) Defining the major core processes of the business. (2) Determining the key output of the core processes and key customers they serve. (3) Creating a high-level map of the core or strategic process.

Define phase is a phase that establishes the specific needs of the customer or often known as VOC (Voice of customers) The aim of phase is to record all the variables deemed important by customers as CTQ, then give the measured values. The measured variable is named as a substitute quality characteristics or Critical To Quality (CTQ). Another step is to identify the stages defining the processes that accompany the CTQ.

\section{Measure}

Measure is a logical follow-up measure to define steps and a bridge to the next step. According to Pete and Holpp (2005: 48), this phase has two main objectives, namely; (1) Obtaining the data to validate and qualify problems and opportunities. Usually, this is critical information to improve and supplement the articles of association of the first project. (2) Starting touching facts and figures that provide clues about the root problem.

Six Sigma takes a business perspective to the process and uses this view to set priorities and make good decisions about what these measures required.

This process includes three categories, namely; (1) Output or the end result: the final outcome of the process. Measures of output focus on delivery, defects, complaints and the final results on the effects of the longer period (profit, satisfaction, etc.). (2) Process: things that can be tracked / traced and measured. These items usually help the team to begin determining the root of the problem. (3) Input: things that exist in the process of changing the output.

\section{Analyze}

Analyze aims to find the root cause. One of the principles of DMAIC problem-solving is considering various types of causes, so do not let bias. DMAIC narrows the search for the cause of the analyze phase. This phase starts with combining the experience, data/ size, and review of the process and then structured as the initial presumption, or the hypothesis of the root problem. Cycle continued with the hypothesis repaired or rejected, until the true root of the problem can be identified and verified with data.

\section{Improve}

Improve is the process of implementing an action plan to implement the Six Sigma quality improvement. The plan describes the allocation of resources and priorities or alternatives done. In this phase, the quality improvement team must decide targets to be achieved, why the action plan is carried out, in which the action plan will be carried out, when the plan will be done, who is responsible for the action plan, how to implement the action plan and how much charge implementation as well as what are the positive benefits of the implementation of the action plan.

The effectiveness of the plan of actions taken will appear on the decrease in the percentage of the cost of 
JURNAL BISNIS \& MANAJEMEN

ISSN 1412 - 3681

the failure of the quality of the total sales value in line with the increasing capability sigma. Each action plan is implemented to be evaluated for its effectiveness through the achievement of performance targets in Six Sigma quality improvement program which is lowering the target failure DPMO towards zero (zero defect oriented) or achieving process capability at a rate greater than or equal to Six Sigma.

There are two reasons in standardizing, namely; (1) If the quality improvement measures or solutions to problems are not standardized, it is possible that after a certain period of time, management and employees will reuse the old way of working that brings back the problems that have been resolved. (2) If the quality improvement measures or solutions to problems are not standardized and documented, it is possible after a certain period of time when a change of management and employees, people will use the new way of working that will bring back the problem that has been resolved by the previous management and employees.

\section{Control}

The main target of control measure is to avoid harmful habits and processes in the previous activity. The specific tasks of control that must be finishes with this step are; (1) Developing a monitoring process to track the changes that must be determined. (2) Creating a response plan to deal with problems that may arise. (3) Helping to focus the attention of the management of the critical measures that provide the latest information regarding the final outcome of the project $(Y)$, and against measures of key processes $(X)$.

\section{METHOD}

The method used in this research is descriptive analysis method. This method is used to determine how to control the quality of Docmart-like shoes that have been made by the company and to determine the impact, if DMAIC's control method is applied in footwear products of CV. Berkah Abadi. Descriptive method will be explained on the company's current situation based on the facts and data that have been collected and investigated the efforts made in the process of quality control.
Jurnal Bisnis \& Manajemen, 2016, Vol. XVII, No. 1, 3-12

This study used Statistical Process Control (SPC) as a tool to implement the Six Sigma method of quality control.

\section{Design Analysis}

Analysis of the data used to answer the identification of the problem is to use qualitative and quantitative analysis. Qualitative analysis is limited to data processing techniques, such as data checking and tabulation, for example: reading tables, graphs or figures are available, then the description and interpretation. Quantitative analysis uses an analytical tool (model). The model used is the model with the Six Sigma's DMAIC method (Define, Measure, Analyze, Improve, Control) using 7 tools TQM. So the end result and the best techniques to conduct quality control can be known.

The first problem is identifying of what factors causing defects in the Docmart-like product of CV Berkah Abadi. Interviews were conducted with owners, CEO, and employees. Interview method used is structured and deep interviews. In this study, field observations were also conducted, by 10 days of observation in February at each post production of CV. Berkah Abadi. They were used to collect primary data, so that the factors that influence the production process until the occurrence of defective products can be known. The second problem is identifying the impact of the implementation of Six Sigma in improving product quality of CV. Berkah Abadi. The DMAIC method of 7 tools of TQM will be used to find the answer to this question.

\section{Sample Selection}

This study used a non-probability sampling technique. The sampling did not provide equal opportunities for every Docmart-like type of shoes as population to be elected as samples. This study only examined the shoes under the brand BNA of CV Abadi Jaya. Therefore, sampling method in this research is purposive sampling, where samples of the were population taken based on certain considerations, Sugiyono (2011: 64).

\section{RESULT AND DISCUSSION}

\section{Factors Contributing to Defective Products}

To achieve customer satisfaction, every company 
does its best to meet the consumer's expectation of a product. This also applies for manufacturing companies. CV Berkah Abadi is an SME that tries to improve product quality and reduce defective products. To achieve these objectives, the company must know the causes of defects and what are the root causes. Afterwards, the company anticipates the processes that cause these defects. The factors that cause defects in the CV Berkah Abadi can be seen through Man, Method, Materials and Environment (Besterfield, Dale H, 2011) as follows:

\section{Man}

The production process of Docmart-like shoes of CV. Berkah Abadi are done using human power. Each course of the work is done and moved by human power. The negligence of manpower plays an important role in producing a defective product. Human negligence or carelessness can lead to deviations in the production process.

\section{Material}

Raw materials are supplied from other companies, and this is one of the causes of product defects. Raw materials with soiled or torn surfaces are things that can be found.

\section{Method}

The method is directly related to humans. Mistakes in using machines, tools, and raw materials in the production process could lead to product defects that can be detrimental to the company.

\section{Machine}

Docmart-like shoe production is processed by CV.Berkah Abadi using several machines that are operated directly by humans. Machine with bad performance causes imperfect production process, so it can lead to defective products.

\section{Environment}

CV Berkah Abadi operates a house that is used as shoe production factory. The work environment is not too clean that dirty floor can result in stained raw materials and products in the production and storage stages.

\section{Application of Six Sigma At Docmart-like Shoe Production Process}

CV Berkah Abadi has been producing Docmark-like shoes, but defected product still occurs amongst its production result. So, Six Sigma with DMAIC method are more suitable to be applied than DMADV method (Define, Measure, Analyze, design, Verify). DMADV method is better suited to apply when a process or a product not yet existing or new. Sig sigma is used to determine how DMAIC process can be applied on an SME. In define measure, Pareto diagrams were used as tools to find out the cumulative percentage of each type of disability that occurs. In measure, p-chart control tests were used to ensure the data obtained is still at the predetermined limit. In analyze measure, fishbone diagram was used to unravel the factors that lead to defective products. In improve measure, FMEA (Failure Mode and Effect Analysis) was used to determine the level of any factor that should be prioritized for improvement.

\section{Define}

In define phase, data collection was used to determine how many defective products resulting from the production process of Docmart-like shoes of CV. Berkah Abadi. The collection of data determined how many defects occurred and CTQ (Critical To Quality) existed in every day production. Data collection on the number of defective products was conducted for 10 days in February.

From the data obtained, it can be analyzed that the defect occurred during the 10 days of production activities by 67 for a total of as many as 49 product defects. To determine the distribution and concentration problems that occur, Pareto diagram was used. Based on data, Pareto diagram can be seen as follow:

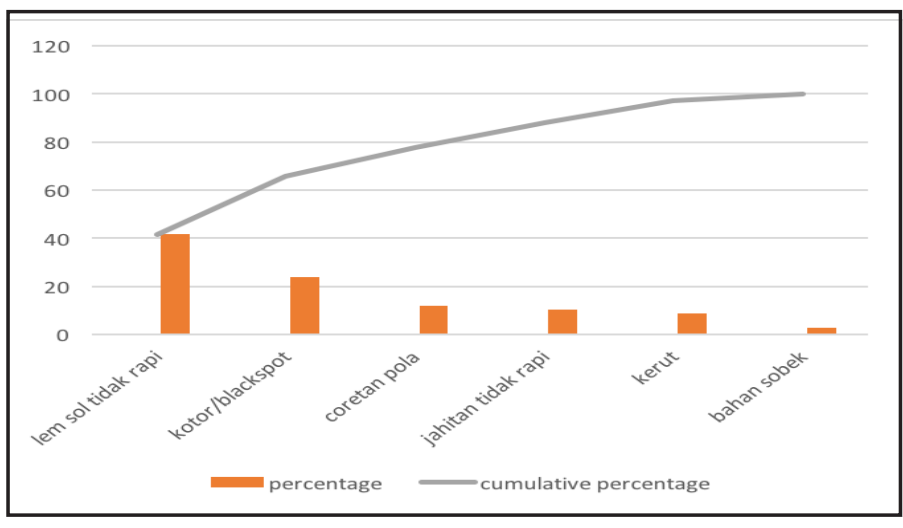

Figure 1 Pareto Diagram Potential CTQ 
JURNAL BISNIS \& MANAJEMEN

ISSN 1412 - 3681

Based on Pareto picture above, the level of defect that most often occurred in the production process was the mark of dried glue/ untidy application of causing stains on the surface of the shoe reaching $41.79 \%$. Next is the occurrence of dirt/stain by 16 times or $23.88 \%$ of the total errors occurred. The third type of defect is regarding the squiggled pattern of shoes that occurred 8 times with a percentage of $11.94 \%$ of the total errors occurred. The next type of defect is untidy stitches that occured 7 times with percentage rate of $10.44 \%$ of the total defect occurred. Wrinkles on upper shoes also accured 6 times, or $8.95 \%$ of total errors occurred. The next mistake was the discovery of torn materials as much as 2 times or $2.98 \%$ of total errors that occurred on 10-day production in February.

\section{Measure}

The first step in measure phase was to identify things that were considered important in the production process that were directly related to CTQ. CTQ potential can be identified in the study were the types of defects that may occur in footwear products.

Based on observations, there were several problems often occurred in the production process of Docmartlike shoes of BNA of CV. Berkah Abadi, namely :

\section{Sloppy Stitches}

There were seams and stitches that did not fit the pattern of the body shoes.

\section{Stains}

There were black stains on the shoes or dirt due to dust, such as oil or engine oil.

\section{Graffiti pattern on the shoes}

There were streaks on the shoes in the cut and sewing patterns. These streaks were formed from the beginning of the production when raw materials were cut to create the desired pattern shoes.

\section{Untidy Glued Soles}

Soles were not glued perfectly between the upper and bottom shoes.

\section{Wrinkles on upper shoes}

Wrinkles on the upper shoes occurred because the shoes were not perfectly ovened.
Jurnal Bisnis \& Manajemen, 2016, Vol. XVII, No. 1, 3-12

\section{Torn Ipper Shoes}

Shoes looked uneven or torn because there were some frictions at each stage of production.

To ensure that data was not taken out of the tolerance limit, the data is controlled by using the p-chart as a follows:

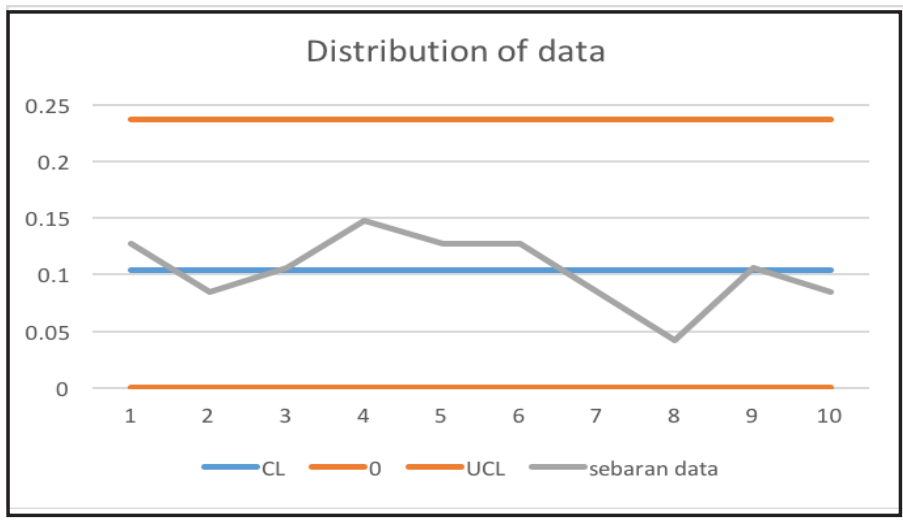

Figure 2 Chart Full Map Shoes That Examined

Based on the figure above, it can be seen that the entire data was obtained within the control limits had been set. It is claimed that the quality control on the CV Berkah Abadistill requires improvement towards the goal of Six Sigma that there are only 3.4 chances of error of one million occasions.

\section{Calculation of Sigma Value}

By calculating the value of DPMO (Defect Per Million Objects) and sigma value, the performance in production can be seen. DPMO can be calculated from the number of defects that occurred, the number inspected, and the number of potential CTQ

Based on the calculation of DPMO and sigma value, it was found that the average value of DPMO in the production process of Docmart-like shoes of CV Berkah Abadi is 38758.87 units with an average of 3.274 sigma values. Based on Six Sigma objectives which tolerate disability 3.4 million times the incidence in the opportunities, CV Berkah Abadi still has to thrive to reduce activities that can lead to the production of defective products.

\section{Analyze}

Phase of analyze was conducted to determine factors that contributed to the defects in the Docmart-like shoe production. In the third step in the DMAIC 
phases, sources and root cause of the production failures were dtermined or identified.

Factors that could cause the failure of products can be seen and parsed through a fish-bone diagram. The fishbone diagram shows all types of defects that fell into the category of potential CTQ, namely stains, sloppy stitching, untidy glue, wrinkles, streaks on the surface of the shoe and tears on the surface of the shoe.

To be able to see an outline of the fault location of

\section{Improve}

Improve phase is an action plan to implement the Six Sigma quality improvement. After knowing the cause of defects of BNA brand produced by CV. Berkah Abadi, a recommendation or proposed remedial action was proposed in general as an effort to reduce the defective products by using FMEA.

Change was done by using the FMEA spreadsheet brainstorming with the production company. Brainstorming is conducted to determine the impact, severity, and occurrence of each cause, and

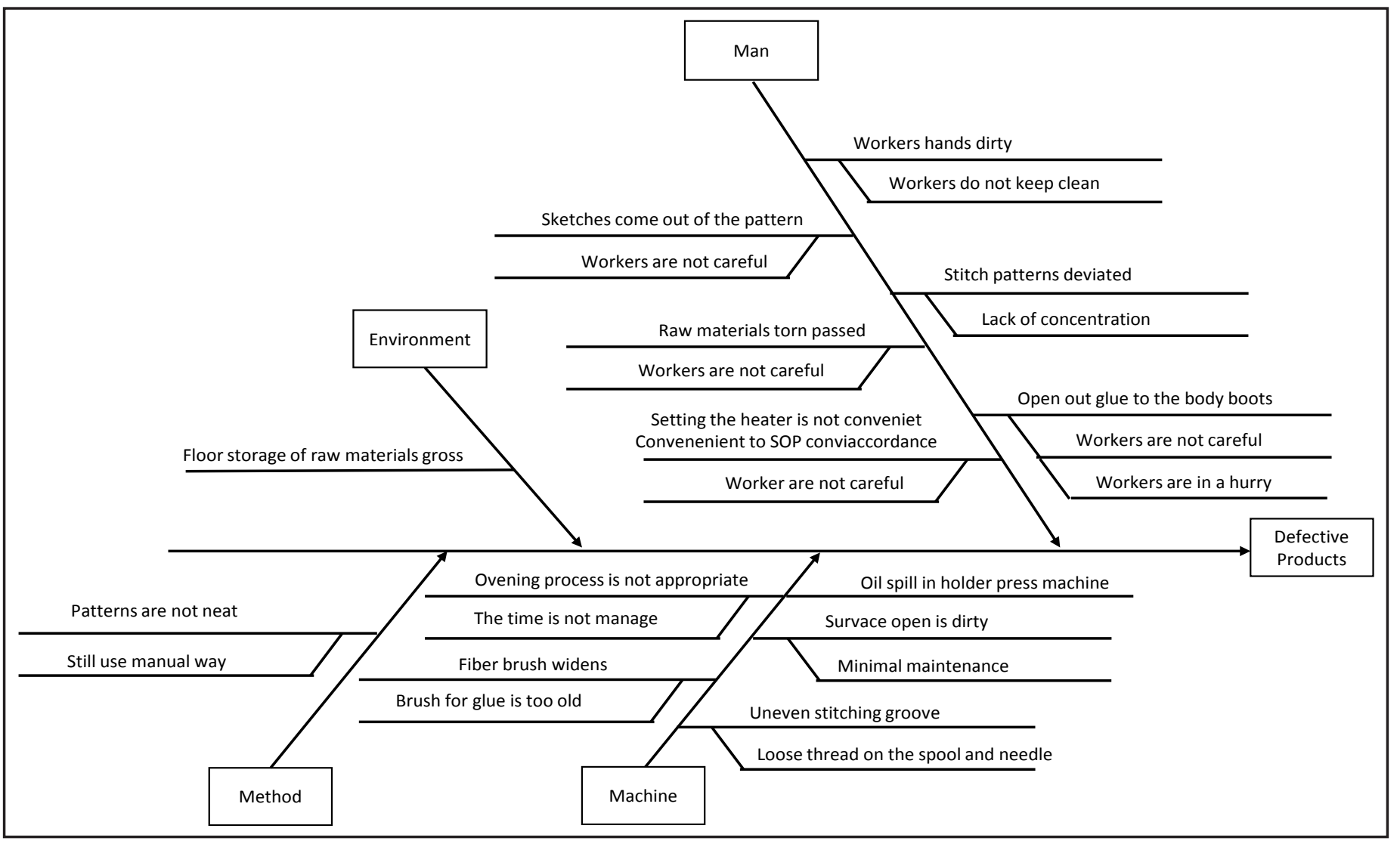

Figure 3 Fishbond Diagram for Dogmart Shoes Brand BNA

defective products of Docmart-like shoes of BNA brand, a fishbone was made to summarize all of the factors led to defective products. Here is a fishbone diagram for the overall defects that occurred in BNA brand:

Based on the fishbone diagram, the defects that occurred the production, human error is the most common cause with 6 factors. Errors on the machine has 5 factors that place them on the second position. Errors in methods and environments have each one factor that can cause defective products. the effectiveness value between 1-10, the scoring done based on the considerations contained in the references (appendix table severity rating, probability of occurrence and effectiveness).

The value was obtained from the probability of occurrence of potential possibility of the failure modes based on time of production. Severity values were consequences that may result from the occurrence of errors in the production process. Value is the value to the effectiveness of a prevention/preventive action if it is done on the factors that cause this type of error. 


\section{JURNAL BISNIS \& MANAJEMEN}

ISSN 1412 - 3681

The result of multiplying the value of probability of occurrence, severity and effectiveness of the Risk Priority Number is the magnitude of the interests of the repair activities.

\section{Control}

Phase of control is the last stage of the DMAIC method. At this stage, improvement plans were made. Once the improvement plan has been implemented, the reuse map control was measured and compared with the number of defects on before and after the repair process. At the stage of production control, CV. Berkah Abadi should continue to monitor every production process done by humans and machines. In this stage, the treatment on each tool and machine part must be done so that all the production processes can run as expected. Therefore, to maintain product quality, CV. Berkah Abadi must continue to implement the Plan, Do, Control and Action as has been done on Six Sigma methods of control.

\section{CONCLUSION}

Based on the analysis of research has been done on the production process of Docmart-like shoes with BNA brand produced by CV. Berkah Abadi, it can be concluded that the company's production process still produces defective products. Application of the method of quality control in Micro Small Medium Enterprises is something that can be done with the cooperation and awareness of the stakeholders of the company. This study can be summed up as follows:

In general, factors that cause to defective products are human, machine, method and environment. (1) Man: workers who are not being careful, less focus, and hurrying during the production process as well as the not maintaining the cleanliness can produce defective products. (2) Machine: the lack of care before and after the production process, as well as the use of a machine that is old with incomplete component can generate defective products. (3) Environment: dirty storage of raw materials can cause defective products. (4) Method: production process which is still done manually can increase the probability of error occurrences.

Six Sigma can be implemented not only for big company, but also for SMEs. It is proofed with this research that production process can be improved in SMEs using Sig Sixma implementation. The application of DMAIC (Define, Measure, Analyze, Improve, Control) in CV Berkah Abadi as an SME can be done with the cooperation among employees. The company's performance based on the value of DPMO (Defect Per Million Opportunity) is 38758.87 with sigma value of 3.274 . It is proved that for every 1 million occasions of 38758.87 production process, there will be a possibility for the creation of a defective product.

\section{REFERENCES}

Besterfield, \& Dale, H. (2011). Quality Control, Eight Edition. New Jersey: Pearson Prentice Hall.

Chase, Richard B., F. Robert Jacobs, \& Nicholas J. Aquilano. (2006). Operations Management For Competitive Advantage With Global Cases, Eleventh Edition. New York: McGrawHill International Edition.

Gasperz, Vincent. (2002). Pedoman Implementasi Program Six Sigma Terintegrasi dengan ISO 9001 : 2000, MBANQA \& HACCP. Jakarta: PT Gramedia Pustaka Utama.

Heizer, Jay \& Render, Barry, (2011). Operations Management (10th ed.). Upper Saddle River, New Jersey: PearsonPrentice.

Pande, Pete \& Larry Holpp. (2005). What Is Six Sigma: Berpikir Cepat Six Sigma. Yogyakarta: ANDI

Pande, Peter S., Robert T P. Nouman, \& Roland R. Cavanagh. (2003). Six Sigma Way, Edisi Bahasa Indonesia. Yogyagarta: ANDI.

Pyzdek, Thomas. (2002). The Six Sigma Handbook: Panduan Lengkap Untuk Greenbelt, Blackbelt dan manajer Pada Semua Tingkat. Jakarta: Salemba Empat.

Reid, R. Dan, \& Nada R. Sanders. (2014). Operations Management (5th ed.). New Jersey: John Wiley \& Sons, Inc. 
Schroeder, Roger G., Goldstein, Susan M., \& Swink, Morgan, Steven A. Melnyk, M. Bixby Cooper, Rungtusanatham, M Johny, (2011). \& Janet L. Hartley. (2014). Managing Operations Management (5th ed.). Avenue Operations Across The Supply Chain. of the Americans, New York: McGraw-Hill. Newyork: McGraw-Hill International Edition.

Sugiyonoi. (2011). Metode Penelitian Kuantitatif Kualitatif dan R\&D. Bandung: Alfabeta.

Gijo, E. V., Johny Scaria, \& Jiju Antony. (2011).Application ofSixSigma Methodology to Reduce Defects of a Grinding Process.

Nazir Muhammad. (2005). Metode Penelitian. Jakarta: Ghalia Indonesia. 